\title{
EVALUATION OF BIOACTIVE CONSTITUENTS AND IN-VIVO ANTI-INFLAMATORY ACTIVITY OF HYDROALCOHOLIC LEAVES EXTRACT OF GREWIA HIRSUTA
}

\author{
Mr. Mahendra Jaiswal ${ }^{1}$, Dr. C.K.Tyagi ${ }^{2}$, Dr. Prabhakar Budholiya ${ }^{3}$ \\ ${ }^{1}$ Research Scholar, College of Pharmacy, Sri Satya Sai University of Technology and Medical Science \\ Sehore, (M.P.) \\ ${ }^{2}$ Dean \& Professor, College of Pharmacy, Sri Satya Sai University of Technology and Medical Science \\ Sehore, (M.P.) \\ ${ }^{3}$ Associate Professor, College of Pharmacy Sri Satya Sai University of Technology and Medical Science \\ Sehore, (M.P.)
}

Article Info: Received 10 February 2021; Accepted 15 March 2021

DOI: https://doi.org/10.32553/jbpr.v10i2.853

Corresponding author: Mr. Mahendra Jaiswal

Conflict of interest statement: No conflict of interest

\section{Introduction}

Plants represent the main source of molecules for the development of new drugs, which intensifies the interest of transnational industries in searching for substances obtained from plant sources, especially since the vast majority of species have not yet been studied chemically or biologically, particularly concerning antiinflammatory action. Anti-inflammatory drugs can interfere in the pathophysiological process of inflammation, to minimize tissue damage and provide greater comfort to the patient. Therefore, it is important to note that due to the existence of a large number of species available for research, the successful development of new naturally occurring anti-inflammatory drugs depends mainly on a multidisciplinary effort to find new molecules. Although many review articles have been published in this regard, the majority presented the subject from a limited regional perspective. Thus, the current article presents highlights from the published literature on plants as sources of anti-inflammatory agents. A search for effective medication with lesser or no side effects is the need of the hour. Hence the current study is focused at evaluating the anti-inflamatory potential of Grewia hirsuta. The leaves of G. hirsuta were subjected to solvent extraction with ethanol. The best screened extract was further evaluated for it phytochemical profile by qualitative and quantitative phytochemical analysis. The results of the study suggest that Grewia hirsuta possesses significant antiinflamatory potential. With further mechanistic studies it can be proved as a better source of natural antiinflamatory agents.

Keywords: drugs; inflammation; bioactive compounds

\section{Introduction}

Inflammation is a part of the complicated biological reaction of vascular tissues to harmful stimuli, including pathogens, damaged cells or irritants. It is characterized via redness, swollen joints, joint pain, its stiffness and lack of joint characteristic. Inflammation is presently treated via NSAIDs. Unfortunately these capsules motive elevated danger of blood clot ensuing in heart assaults and strokes. Inflammation is a normal, protective reaction to tissue damage caused by physical trauma,

noxious chemical compounds or

microbiological marketers.

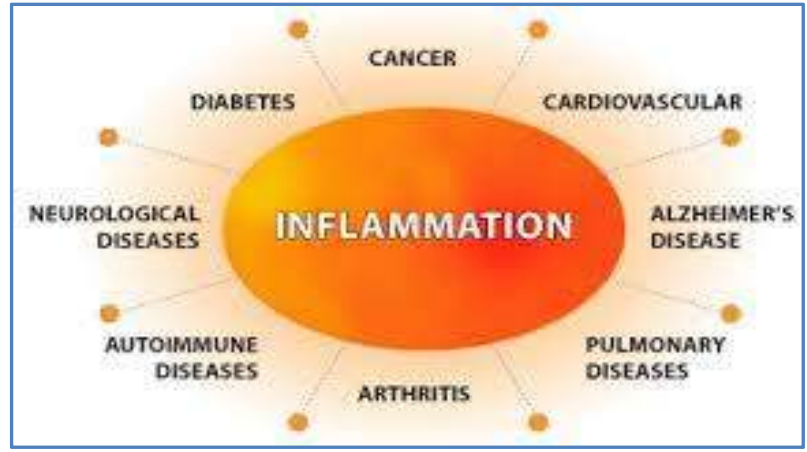

Figure 1.1: Inflammation 
Inflammation (from Latin: inflammation) is part of the complex biological response of body tissues to harmful stimuli, such as pathogens, damaged cells, or irritants, and is a protective response involving immune cells, blood vessels, and molecular mediators. The function of inflammation is to eliminate the initial cause of cell injury, clear out necrotic cells and tissues damaged from the original insult and the inflammatory process, and initiate tissue repair.

\section{Causes of Inflammation}

Physical:

- Burns

- Frostbite

- Physical injury, blunt or penetratin

- Foreign bodies, including splinters, dirt and debris

- Trauma

- Ionizing radiation

Biological:

- Infection by pathogens

- Immune reactions due to hypersensitivity

- Stress

Chemical:

- Chemical irritants

- Toxins

- Alcohol

Psychological:

- Excitement

\section{Types of Inflammation}

There are mainly two types of inflammation which are as follows:

\subsubsection{Acute inflammation}

It is associated with increased vascular permeability, capillary infiltration and emigration of leukocytes.

\subsubsection{Chronic infection}

It is related to infiltration of mononuclear immune cells, macrophages, monocytes, neutrophils, fibroblast activation, proliferation (angiogenesis) and fibrosis. Inflammation is a commonplace scientific situations and rheumatoid arthritis (RA) is a persistent debilitating autoimmune disease. That affects approximately $1 \%$ of the population in evolved nations. The classic symptoms of inflammation are neighborhood redness, swelling, pain, warmness and loss of characteristic.

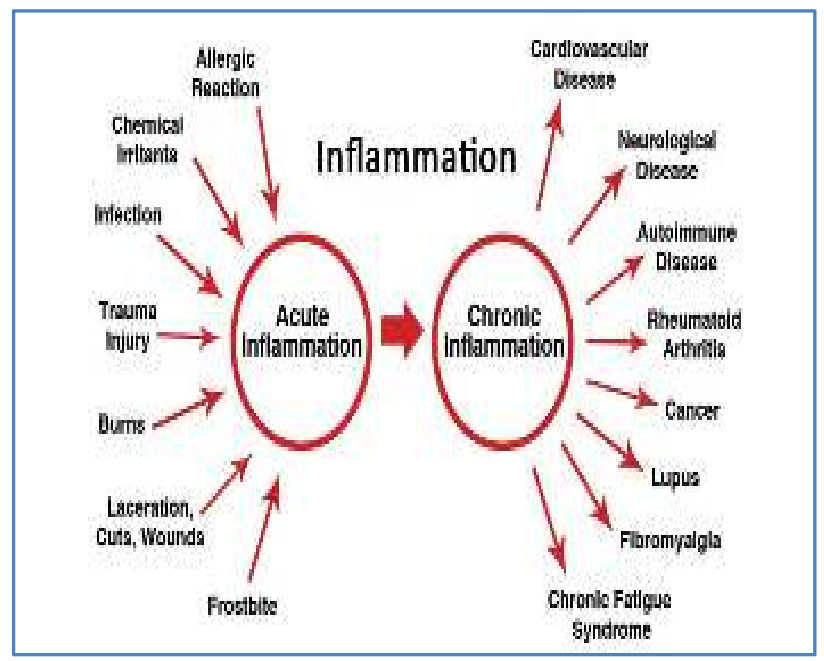

Figure 1.2: Type of Inflammation

\section{Materials and Methods}

\subsection{Plant material collection}

The leaves of Grewia hirsuta were collected from Vindhya herbal nursery, Bhopal (Madhya Pradesh) in the month of August, 2020. Dried leaves of Grewia hirsuta were preserved in plastic bags, closed tightly and powdered as per the requirements.

\subsection{Extraction procedure by maceration process}

Dried powdered leaves of Grewia hirsuta has been extracted with hydroalcoholic solvent (ethanol: water: 70:30) using maceration process for $48 \mathrm{hrs}$, filtered and dried using vacuum evaporator at $40^{\circ} \mathrm{C}$.

\subsection{Determination of percentage yield}

The percentage yield of each extract was calculated by using following formula:

$$
\text { l'erentage yicld }-\frac{\text { Weight of Exrract }}{\text { Weight of powdecod drug }} \times 100
$$

\subsection{Phytochemical Screening}

The Grewia hirsuta extract acquire was subjected to the precursory phytochemical analysis following standard methods by Khandelwal and Kokate. The extract was screened to identify the presence of various 
active principles of alkaloids, glycosides, phenols, flavonoids, Amino acid, Cabohydrates, Terpenoids, Saponins, Steroids.

\subsection{Total flavonoids content estimation}

Determination of total flavonoids content was based on aluminium chloride method. $10 \mathrm{mg}$ quercetin was dissolved in $10 \mathrm{ml}$ methanol, and various aliquots of $5-25 \mu \mathrm{g} / \mathrm{ml}$ were prepared in methanol. $10 \mathrm{mg}$ of extract dissolved in $10 \mathrm{ml}$ methanol and filter. Three $(1 \mathrm{mg} / \mathrm{ml})$ of this extract was for the estimation of flavonoid. 1 $\mathrm{ml}$ of $2 \% \mathrm{AlCl}_{3}$ methanolic solution was added to $3 \mathrm{ml}$ of extract or standard and allowed to stand for $15 \mathrm{~min}$ at room temperature; absorbance was measured at $420 \mathrm{~nm}$.

\subsection{Total alkaloids content estimation}

The plant extract (1mg) was dissolved in methanol, added $1 \mathrm{ml}$ of $2 \mathrm{~N} \mathrm{HCl}$ and filtered. This solution was transferred to a separating funnel, $5 \mathrm{ml}$ of bromocresol green solution and $5 \mathrm{ml}$ of phosphate buffer were added. The mixture was shaken with $1,2,3$ and $4 \mathrm{ml}$ chloroform by vigorous shaking and collected in a $10-\mathrm{ml}$ volumetric flask and diluted to the volume with chloroform. A set of reference standard solutions of atropine $(40,60,80,100$ and $120 \mu \mathrm{g} / \mathrm{ml}$ ) were prepared in the same manner as described earlier. The absorbance for test and standard solutions were determined against the reagent blank at $470 \mathrm{~nm}$ with an UV/Visible spectrophotometer. The total alkaloid content was expressed as $\mathrm{mg}$ of AE/100mg of extract.

\subsection{Formalin-induced Anti- inflammatory activity of leaves of Grewia hirsuta}

\section{Animals:-}

Wistar rats (150-200gm) were group housed $(\mathrm{n}=6)$ under a standard $12 \mathrm{~h}$ light/dark cycle and controlled conditions of temperature and humidity $\left(25 \pm 2{ }^{\circ} \mathrm{C}, 55-65 \%\right)$. Rats received standard rodent chow and water ad libitum. Rats were acclimatized to laboratory conditions for 7 days before carrying out the experiments. All the experiments were carried in a noise-free room between 08.00 to $15.00 \mathrm{~h}$. Separate group $(n=6)$ of rats was used for each set of experiments. The animal studies were approved by the Institutional Animal Ethics Committee (IAEC), constituted for the purpose of control and supervision of experimental animals by Ministry of Environment and Forests, Government of India, New Delhi, India.

\section{Toxicity study}

Preliminary experiments were carried out on rats $(n=6)$. Hydroalcoholic Extract of leaves of Grewia hirsuta were administered orally in different doses to find out the range of doses which cause zero and $100 \%$ mortality of animals. Acute oral toxicity was conducted according to the method of Organisation for Economic Co-operation and Development (OECD) (OECD; 2001). Animals were kept fasting providing only water, extract were given p.o. in doses of 500, 1000 and 2000 $\mathrm{mg} / \mathrm{kg} / \mathrm{p}$.o. administered orally for 4 days of six groups of rats $(n=6)$ and the animals were kept under observation for mortality as well as any behavioral changes for evaluation of a possible anti-inflammatory effect (Singh et al., 2010).

\section{Formalin-induced paw edema model}

The animals were divided into four groups of six animals each and were fasted for a period of $24 \mathrm{~h}$ prior to the study. Group 1 was treated as control (formalin $(0.2 \mathrm{ml}$ of $2 \% \mathrm{v} / \mathrm{v}$ freshly prepared formalin solution prepared in distilled water), Group 2 was received Diclofenac Sodium $30 \mathrm{mg} / \mathrm{kg}$, p.o. Group 3 were treated with Hydroalcoholic Extract of leaves of Grewia hirsuta (HEGH) (100mg/kg, p.o.). Group 4 were treated with Hydroalcoholic Extract of leaves of Grewia hirsuta (HEGH) (100mg/kg, p.o.). The thickness was measured before injecting the formalin and after injecting the formalin everyday at a fixed time for seven consecutive days using a vernier caliper (precision) (Singh et al., 2010).

\section{Anti-inflammatory activity}

\section{Experimental designs}

Group -1: Control

Group -2: Diclofenac Sodium (Standard)

Group -3: Hydroalcoholic Extract of leaves of Grewia hirsuta (HEGH) (100mg/kg, p.o.) 
Group -4: Hydroalcoholic Extract of leaves of Grewia hirsuta (HEGH) (200mg/kg, p.o.)

\section{Results and Discussion}

\subsection{Result of Percentage Yield}

The yield of extracts obtained from samples using hydroalcohol solvents are depicted in the table

Table 3.1: \% Yield of Grewia hirsuta (Leaves)

\begin{tabular}{|l|l|l|}
\hline S. No. & Solvents & \% Yield \\
\hline 1. & Hydroalcoholic (ethanol: water) & 4.85 \\
\hline
\end{tabular}

\subsection{Phytochemical screening of extract}

Small portion of the dried extracts was subjected to the phytochemical tests using standard methods to test for alkaloids, glycosides, saponins, flavonoids and phenol separately for extracts of all samples. Small amount of each extract was suitably resuspended into the distilled water to make the concentration of $1 \mathrm{mg}$ per $\mathrm{ml}$. The outcomes of the results are discussed in the table

Table 3.2: Phytochemical screening of extract of Grewia hirsuta

\begin{tabular}{|l|l|l|}
\hline S.No. & Constituents & $\begin{array}{l}\text { Hydroalcoholic } \\
\text { Extract }\end{array}$ \\
\hline 1. & $\begin{array}{l}\text { Alkaloids } \\
\text { Dragendroff's test } \\
\text { Hager's test }\end{array}$ & $\begin{array}{l}\text { +ve } \\
+\mathrm{ve}\end{array}$ \\
\hline 2. & $\begin{array}{l}\text { Glycosides } \\
\text { Legal's test }\end{array}$ & $+\mathrm{ve}$ \\
\hline 3. & $\begin{array}{l}\text { Flavonoids } \\
\text { Lead acetate } \\
\text { Alkaline test }\end{array}$ & $\begin{array}{l}+\mathrm{ve} \\
+\mathrm{ve}\end{array}$ \\
\hline 4. & $\begin{array}{l}\text { Phenol } \\
\text { Ferric chloride test }\end{array}$ & $+\mathrm{ve}$ \\
\hline 5. & $\begin{array}{l}\text { Proteins } \\
\text { Xanthoproteic test }\end{array}$ & $+\mathrm{ve}$ \\
\hline 6. & $\begin{array}{l}\text { Carbohydrates } \\
\text { Fehling's test }\end{array}$ & $+\mathrm{ve}$ \\
\hline 7. & $\begin{array}{l}\text { Saponins } \\
\text { Foam test }\end{array}$ & $\begin{array}{l}\text { Diterpenes } \\
\text { Copper acetate test }\end{array}$ \\
\hline 8. & $+\mathrm{ve}$ \\
\hline
\end{tabular}

Table present above reveals the phytochemical constituents ofGrewia hirsuta. It shows that saponins, tannins, glycosides, alkaloids, carbohydrates, amino acids, phenolic compounds and flavonoids are present in the plant. This indicates the efficacy of the plant for medicinal uses.

3.3 Results of estimation of total flavonoids and alkaloid content

Table 3.3: Estimation of total flavonoids and alkaloid content of Grewia hirsuta

\begin{tabular}{|l|l|l|l|}
\hline $\begin{array}{l}\text { S. } \\
\text { No. }\end{array}$ & Extract & $\begin{array}{l}\text { Total flavonoids } \\
\text { content } \\
\text { (mg/ 100 } \mathbf{~ m g ~ o f ~} \\
\text { dried extract) }\end{array}$ & $\begin{array}{l}\text { Total alkaloid } \\
\text { content } \\
\text { (mg/ 100 } \mathbf{~ m g ~ o f ~} \\
\text { dried extract) }\end{array}$ \\
\hline 1. & Hydroalcoholic & 4.028 & 5.251 \\
\hline
\end{tabular}

3.4 Results of Formalin-induced Antiinflammatory activity of leaves of Grewia hirsuta

Table 3.4: Effect of different extracts on paw oedema induced by formalin in rats

\begin{tabular}{|l|l|l|l|}
\hline Treatment & $\begin{array}{l}\text { Dose } \\
(\mathbf{m g} / \mathbf{k g})\end{array}$ & $\begin{array}{l}\text { Mean } \\
\text { differences in } \\
\text { Paw Volume } \\
(\mathbf{m l})\end{array}$ & $\begin{array}{l}\text { Percentage } \\
\text { of } \\
\text { Inhibition } \\
(\%)\end{array}$ \\
\hline Control & $\begin{array}{l}0.2 \mathrm{ml} \text { of } \\
2 \% \mathrm{v} / \mathrm{v}\end{array}$ & $4.80 \pm 0.20$ & -- \\
\hline Diclofenac & $30(\mathrm{mg} / \mathrm{kg})$ & $3.50 \pm 0.21^{*}$ & 96.0 \\
\hline $\begin{array}{l}\text { Hydroalcoholic } \\
\text { leaves extract } \\
\text { Grewia hirsuta }\end{array}$ & $100(\mathrm{mg} / \mathrm{kg})$ & $3.95 \pm 0.21$ & 85.00 \\
\hline $\begin{array}{l}\text { Hydroalcoholic } \\
\text { leaves extract } \\
\text { Grewia hirsuta }\end{array}$ & $200(\mathrm{mg} / \mathrm{kg})$ & $3.69 \pm 0.22$ & 89.00 \\
\hline
\end{tabular}

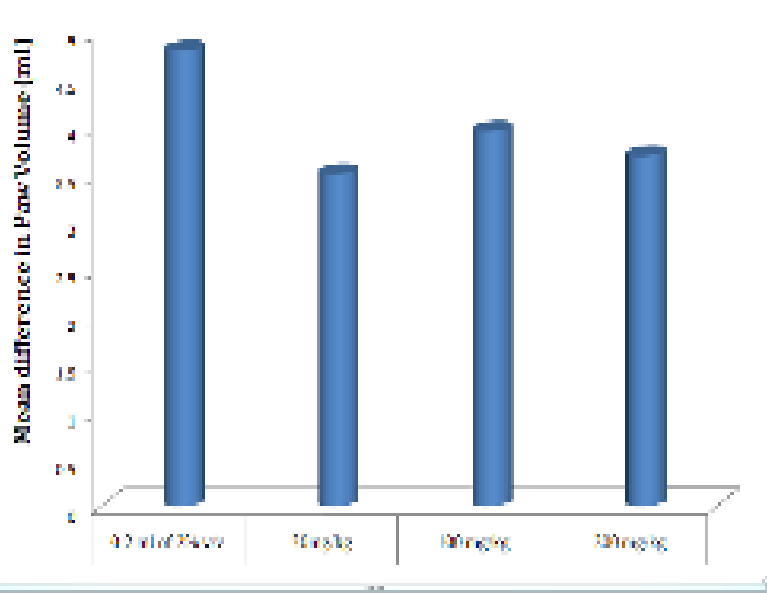

Figure 3.1: Effect of different extracts on paw oedema induced by formalin in rats 
Evaluation of the anti-inflammatory activity of the Hydroalcoholic Extract of leaves of Grewia hirsuta was performed using the formalininduced rat paw oedema model using diclofenac sodium as the reference drug. Mean changes in paw oedema thickness of animals treated with the tested compounds from induction of inflammation was measured, together with the inhibition percent of oedema by the tested extracts at 2 dose level $100 \mathrm{mg} / \mathrm{kg}$ and $200 \mathrm{mg} / \mathrm{kg}$. Results shown that all of the tested extract $200 \mathrm{mg} / \mathrm{kg}$ was found more active.

\section{Conclusion}

Small portion of the dried extracts was subjected to the phytochemical tests using standard methods. Phytochemical screening reveals that presents of various phytoconstituents such as alkaloids, glycosides, saponins, flavonoids carbohydrates and proteins separately for hydroalcoholic extract of Grewia hirsuta. Total alkaloid and flavonoids (mg/100mg) was found in hydroalcoholic extract of Grewia hirsuta 5.251 and $4.028 \mathrm{mg} / 100 \mathrm{mg}$ respectively. Evaluation of the anti-inflammatory activity of the Hydroalcoholic Extract of leaves of Grewia hirsuta was performed using the formalininduced rat paw oedema model using diclofenac sodium as the reference drug. Mean changes in paw oedema thickness of animals treated with the tested compounds from induction of inflammation was measured, together with the inhibition percent of oedema by the tested extracts at 2 dose level $100 \mathrm{mg} / \mathrm{kg}$ and $200 \mathrm{mg} / \mathrm{kg}$. Results shown that all of the tested extract $200 \mathrm{mg} / \mathrm{kg}$ was found more active.

\section{Reference}

1. World Health Organization, 1998 "Quality control methods for medicinal plant materials", Published by WHO, Geneva, 152.

2. El SN and Karakava S., 2004, "Radical scavenging and iron-chelating activities of some greens used as traditional dishes in Mediterranean diet". Int $J$ Food Sci Nutr, vol.55 (1), 152.
3. Samy PR, Iushparaj PN, Gopalakrishnakone PA. 2008, "Compilation of bioactive compounds from Ayurveda Bioinformation”, 153.

4. Subhose V, Narian A. 2005, "Basic principles of pharmaceutical science in Ayurvěda". Bull Indian Inst Hist Med Hyderbad, vol. 35, 153.

5. Ballabh B and Chaurasia OP. 2007, "Traditional medicinal plants of cold desert Ladakh--used in treatment of cold, cough and fever'.J Ethnopharmacol, 112: 341, 153.

6. Dev S, 1997, "Ethnotherapeutic and modern drug development: The potential of Ayurveda". Current Sci, 1997, vol. 73, 153-154.

7. Perumal Samy R and Ignacimuthu S., 1998, "Screening of 34 Indian medicinal plants for antibacterial properties". J Ethnopharmacol, 153.

8. Perumal Samy R and Gnacimuthu SI., 2000, "Antibacterial activity of some folklore medicinal plants used by tribals in Western Ghats of India". J Ethnopharmacol, 153-154.

9. Kamboj V P., 2000, "Herbal medicine Some comments. Current Sci", 153.

10. Rabe and Staden J V., 1997, "Antibacterial activity of South African plants used for medicinal purposes". J Ethnopharmacol, 153.

11. Nayar M P., 1987, "The ecological biogeography of the lowland endemic tree flora". Bull Bot Surv Ind, 1987, page no. 153.

12. Cox PA, 1990, "Ethnopharmacology and the search for new drugs Bioactive Compounds from Plants Ciba Foundation Symposium 154”, Chichester, John Wiley \& Sons, 153.

13. Cox P, Balick M., 1994, "The ethnobotanical approach to drug discovery". Sci American, 1994, Page no.page no. 153 .

14. Tiwari S, Singh A.2004, "Toxic and sub-lethal effects of oleadrin on biochemical parameters of freshwater air breathing murrel, Chant punctatus 
(Bloch)". Indian J Exp Biolo, 42: 153154.

15. Tiwari S., 1998, "Plants: A Rich Source of Herbal Medicine. Journal of Natural Products", Vol 1, 154.

16. Ved DK, Mudappa A, Shankar D., 1998, "Regulating export of endangered medicinal plant species-need for scientific vigour". Curr Sci, 75: 154.
17. "Grewia hirsuta Vahl". Plants of the World Online. Royal Botanical Gardens Kew. Retrieved 18 January 2019

18. S. Kumar, BS. Bajwa, Singh Kuldeep and AN. Kalia, 2013 "AntiInflammatory Activity of Herbal Plants: A Review" IJAPBC - Vol. 2(2), AprJun. 